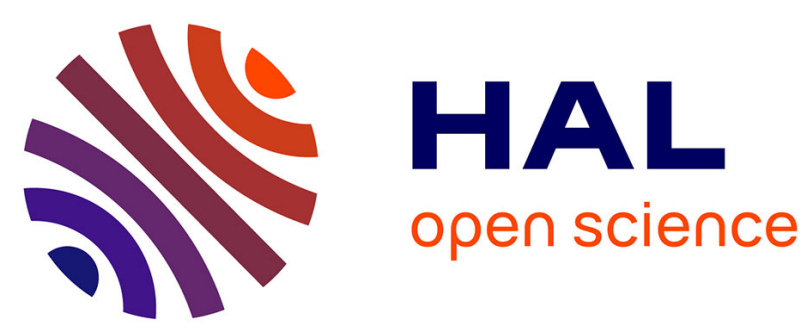

\title{
Making Thatcher's Britain
}

Timothy Whitton

\section{To cite this version:}

Timothy Whitton. Making Thatcher's Britain: Reviewed by Timothy WHITTON. Cercles: Revue Pluridisciplinaire du Monde Anglophone, 2015. hal-01297852

\section{HAL Id: hal-01297852 \\ https://hal.uca.fr/hal-01297852}

Submitted on 6 Apr 2016

HAL is a multi-disciplinary open access archive for the deposit and dissemination of scientific research documents, whether they are published or not. The documents may come from teaching and research institutions in France or abroad, or from public or private research centers.
L'archive ouverte pluridisciplinaire HAL, est destinée au dépôt et à la diffusion de documents scientifiques de niveau recherche, publiés ou non, émanant des établissements d'enseignement et de recherche français ou étrangers, des laboratoires publics ou privés.

\section{다)(1) $(5$}

Distributed under a Creative Commons Attribution - NonCommercial| 4.0 International 


\section{Making Thatcher's Britain}

Ben Jackson \& Robert Saunders (eds.)

Cambridge: Cambridge University Press, 2012

353pp. ISBN-978-1-107-68337-2

Reviewed by Timothy WHITTON

Given that Ben Jackson and Robert Saunders have both written extensively on the history of British politics and political thought in the nineteenth and twentieth centuries, Thatcherism was bound to crop up on their research agenda. As official papers are continually released according to the thirty year rule, so historians are able to broaden their focus on the eleven years during which Mrs Thatcher was Prime Minister and their book, Making Thatcher's Britain, has enabled them to bring together thirteen case studies written by a variety of researchers - including themselves -, professors, lecturers and $\mathrm{PhD}$ students, which in itself shows that "Thatcherism" continues to interest a wide spectrum of scholars. Jackson and Saunders fully acknowledge the fact that a very impressive body of literature has already been devoted to Margaret Thatcher but their claim to novelty lies in the fact that they have adopted a historian's standpoint in order to connect the varieties of Thatcherism not only to an ideology and political creed but to the overall history of twentieth century Britain.

The book is divided into three parts which focus in turn on the different periods during which Thatcherism emerged as a political creed, secondly the way in which it has transformed and moulded Britain across different classes, regions and identities and thirdly, its impact on Britain's place within the wider world is studied. There are two appendices, one of which is devoted to a detailed timeline from Mrs Thatcher's birth in 1925 to her visit to Gordon Brown in Downing Street in 2007. The second appendix contains statistical information about elections in Great Britain, the economy, trade unions and government spending.

The introduction contains a useful biography of Margaret Thatcher explaining her rise to power, her three terms as Prime Minister and her demise in 1990. Readers are also reminded of the main political events that stand out during this period (the Falklands' crisis, the miners' strike, the Poll Tax...) and enabled Thatcher to highly personalise her contribution to British politics. Indeed, the editors refer readily to the "Thatcher effect" in order to enhance the historical perspective they seek to give to their interrogation of the wider impact of Thatcherism. This said, Thatcherism as an ideology, as a deliberate attempt to modify the very foundations of British politics is a line of analysis that cannot be forsaken. Yet, as the period during which Thatcher was Prime Minister of Great Britain draws away in time, it is becoming easier to assess the impact her personal legacy and particular brand of politics has had on Britain. The editors point out the pragmatic changes in society that were ushered in during the Thatcher decade but remain wary about the fundamental upheaval in British culture that Thatcherism is supposed to have brought about. They suggest that in many instances, Britain has been simply swept along by the "wind of change" blowing in from other parts of the world, and that Margaret Thatcher was more the local architect of these changes than the instigator of any major revolution in British politics. To this end, and once again in an attempt to bolster their historical perspective, Jackson and Saunders attempt to identify the space occupied by Thatcherism within the Conservative political tradition. The Conservatives' love of high politics has indeed constantly incited them to insulate the power which they crave from the grubby fray of day to day governing. And it is precisely the fine line drawn between the pressures of office, the force of ideology, adapting to crises and societal changes already 
in motion that historians are now grappling with in order to unravel the confusion and the ambiguities that surround Thatcherism. It is their task to assess why Thatcherism emerged in the first place, to what extent it veered away from the post-war consensus and the traditional Conservative line, if it really did modify the outlook of the British on their society and whether or not promises made in 1979 were actually kept.

The first contribution deals essentially with the evolution of the narrative that gave the theoretical backbone to Thatcherism both within and without a Conservative Party that she had inherited in the throes of a crisis of confidence. Robert Saunders deals with the necessary distinction between ideas and ideology insisting that despite common belief fuelled essentially by Thatcher's own pragmatic approach to such issues, Thatcherism is a subtle blend of the two that was defined both as a constructive project and as a warning against the opposing political forces at bay. While the former was portrayed as being a series of answers to particularly antagonistic situations, the latter blended perfectly with Thatcher's personal brand of eschatological politics all the more so when it came to her main enemy: socialism. Thatcher's anti-socialism was not only a political crusade but also - and mainly - a moral one. To prove this point, Saunders maps out both the moral and political failings of the Labour Party during the seventies and the threat it posed to "free" society that ushered in Thatcherism. He dwells particularly on the period after 1976 when Thatcher was obliged to tack between instinct and political necessity in order to obtain power at the next election especially in the relationship between the Conservatives and the trade unions. To this end, the "Winter of Discontent" occurred appropriately to underline both Labour's failure to govern properly and the need for a new political settlement, opening up a breach that Thatcher was only too glad to use to her full advantage. Saunders concludes by stating that if at the outset Thatcherism was an oppositional creed, the post 1979 task necessarily involved transforming this into a positive programme for government. This is precisely where the narrative of Thatcherism played a vital role, tying up the strands of 1970s' opposition into credible policies for the 1980s in the hope that a radical culture change in Britain would be achieved. Yet when after a decade a majority of Thatcher's enemies had been slain, the resonance of Thatcherism itself had been altered leaving her successors to grapple not only with their own political identities but also with the task of redefining the legacy of their mentor.

The following article written by the co-editor, Ben Jackson, explores the complex relationship between neo-liberalism and Thatcherism by putting the dissemination of this doctrine into a wider historical perspective, in accordance with the book's claim to originality. Jackson bases his analysis on two assumptions namely that neo-liberalism is primarily disseminated via elites and that a great deal of archival evidence still remains insufficiently exploited. The author's initial angle relates to the mobilisation of resources in putting the neoliberal case and he gives a detailed account of how one of the main think tanks, the Institute of Economic Affairs (IEA), emerged to broadcast the neo-liberal message supplied by its extensive network of international intellectuals. Jackson identifies the use British neo-liberals made of this input in defining the specificities of neo-liberalism in and for Britain and points out just how the IEA targeted its highly receptive elite audiences in order to imbue them with the neo-liberal message that in the seventies was also beginning to enjoy a broader penetration of the British press and broadcast journalism. Jackson's last point deals with politicians themselves especially given that the IEA continually claimed to be non-partisan. This said, its agenda framed far more easily within the Conservative Party's outlook and links with the Right seemed far more natural. Nevertheless, Jackson is quick to point out that before taking office and despite surrounding herself with neo-liberal advisors, Mrs Thatcher's own links with the think tanks have yet to be confirmed. Her devotion to the free market, her desire to woo the middle classes by not being over zealous in dismantling the welfare state and her lack of interest in marketing her ideas perhaps explain this. 
The third contribution in this book deals with inflation and Thatcherite thinking, focussing on the period 1975-79. Jim Tomlinson begins by retracing some of the major characteristics of inflation during the twentieth century and then dwells particularly on how the Conservative abhorrence of inflation fed through into Mrs Thatcher's political strategy vis-à-vis unemployment, the unions, and her desire to protect the middle classes. Indeed, for Thatcher, inflation was the Giant that had to be slain to put Britain back onto the road of recovery for it was synonymous with decline. To this end, the Conservatives identified four issues, namely the effects of organised labour on boosting wages claims and thus inflation, unemployment, public spending and borrowing and finally housing. In each case, the situation was examined through the monetarist prism and justification found for the Conservatives to rely on market forces to rebalance. Thus according to them, incomes' policies artificially reinforced union power and once again artificially drove up wages while unemployment could not be solved by government but by reform of the labour market. This latter involved trade union collaboration and conveniently transferred some of the responsibility for high unemployment onto their shoulders. The dilemma concerning public spending and borrowing was particular in that although it could be neatly dealt with by the Conservatives' desire to roll back the frontiers of the state, some of the main monetarist thinkers disagreed, favouring direct control of monetary growth over what they considered to be piecemeal and inappropriate intrusions into the money market. Housing was particular in that a property-owning democracy was central to Thatcher's vision of British society especially if the overall decline were to be addressed. Yet this vision was incompatible with the much broader commitment to economic liberalism that Thatcherism came to symbolise. Indeed, as Tomlinson points out in his conclusion devoted to an assessment of the anti-inflation measures taken during the first years of government, housing is the perfect example of how Thatcher was unprepared to accept the means to the desired end. Otherwise, the failings of monetary policy to curb inflation after 1979 are put down to a neglect of the international context in which the British economy was evolving, the impact of exchange rates being a case in point. Despite this weakness, the Conservatives were able to weather the unemployment storm at the beginning of the eighties not only thanks to contingent factors but mainly because their overall credibility concerning the economy, bolstered by a hard-line attitude towards the unions, was sounder than the Opposition's. The rise of monetarism can be linked to the rise of inflation during the seventies but the success story of monetarism as an economic policy ends there. What it did enable the Conservatives to achieve was a vision of society with less state, a de-legitimisation of the trade unions and the promotion of the declinist case which made it all the more easy to portray socialism as the greatest evil of them all.

In the following article, Matthew Grimley points out that there is a common tendency to view Thatcherism as primarily an economic phenomenon and to overlook its moral and religious dimensions. In the first part of his chapter, he deals with Thatcherism as a reaction to the permissive society and pinpoints Thatcher's - as a woman, mother and politician viewpoints on some of the outstanding legislation that characterised this period and the moral anarchy that she sought to redress. For many, the government's role had gradually been reduced to that of regulating the economy and in doing so, moral issues had somewhat fallen by the wayside. Yet Thatcher's ambition was to create a flourishing society far more than any sort of economic system and it was becoming everyday more apparent to her that any major recovery was doomed without substantial moral regeneration. One of her main targets in this process was the so called molly coddling state, which she considered had not only weakened individual responsibility but also perverted morals and she laid the blame for this squarely on the permissiveness born from socialism and the Labour Party. The remoralising process that Thatcher envisaged was infused with Christian principles but Grimley wonders just to what extent religion contributed to her success in politics. He contends that whilst mainstream 
Conservatives were wary about religion, the morality of Christian principles gave a form of coherence to their political strategy by enabling them to appeal to people's sense of tradition. But while Thatcher continually resorted to moralised language in her rhetoric, her party did little to reverse permissiveness mainly because the Prime Minister's own conception of morality was strongly individualised. There was, even so, one notable exception, namely religious education, which Thatcher believed necessary in order to raise children's awareness about belief and practice. As time passed by in $\mathrm{N}^{\circ} 10$, Thatcher's interest in theology seemed to grow as a throwback to her youth or to plug gaps that her political victories had left in her personal landscape. But because she believed that legislation was a blunt weapon as far as the remoralisation of society was concerned, religious groups had a particular role to play and should they shirk this responsibility, then people would turn to the state, something she wanted to avoid at all costs. Yet Thatcher's disappointment with the Church of England and Anglicanism was on many occasions palpable and often, she needed no prompting to draw unfavourable comparisons with other religious communities. By and large, Thatcher attempted to appeal to the sort of Christian morality that a majority of British people could relate to, however tenuously. It was this stance that ushered her into power but also fuelled one of the paradoxes of her mandates that of preaching morality but engendering rampant materialism.

The last article in this first part looks at the coherences between Thatcherism and Powellism given that both were fighting different battles against different enemies but with the similar weapons of true conservatism. Just like other writers in this book, Camilla Schofield underlines the fact that Thatcher promoted the idea of Britishness in her defence of moral order whereas she was surrounded by supporters who readily used economics in the same crusade. For Powell, on the other hand, the same concept was wielded as a sign of allegiance to the nation and a refusal to turn his back on British sovereignty in the face of American dominance. The author contends that Powellism paved the way for Thatcherism in that it prepared the British electorate for radical politics, and his racist statements were designed to show that Britain was still living in her glorious international past rather than defending today's nation and workers. He used race to thematise the crisis that British society was traversing, the permissiveness that was creeping into all walks of life and above all white sacrifice and white victimisation. But whereas Powell tended to politicise social deviance, Thatcher would readily criminalise it thus justifying her belief in the authority of the state. This said, Powellism is seen by many as a warning of the social dislocation of the 1970s and this is reflected in the broad-based support he found amongst electors disappointed with the political system. The author ends this section of her article by reminding readers of Powell's notorious fall and government immigration policy until 1974. Although Powell no longer had a front seat on the political stage, he had nonetheless started the ball rolling and preached the "transformism" that Thatcher was going to adhere to. Yet whereas many of her colleagues readily believed that the economy could be used to spark off a sea change in attitudes, Thatcher continued to preach the need to stamp out socialism and the corporatism that it had engendered to get the country back on its moral feet again. The trade unions were a case in point given the collective force they could muster up as compared to individual salvation. Interestingly, Thatcher and Powell collided in their disbelief that economic policy could affect the morals of the nation: economics were only a method. Thus Powell spoke out against the Thatcherite economics that attempted to achieve this just as Thatcher herself was wary of Powell's discourse on racial nationalism which she feared would have pushed the Conservatives too far to the right. Instead, in order to integrate the anti-immigration argument into her politics, Thatcher resorted to promoting the responsibility government had to protect the "nation", hence her much quoted analysis of Britain being "swamped" by different cultures. Thatcher and Powell came together once again over the value of war during the 
Falklands' crisis, the former declaring in typical 1940s rhetoric that this conflict underlined the moral responsibilities that the British had both home and abroad. For Powell, the war was an opportunity to lambast the permissiveness ushered in during a period when young people did not experience armed conflict, harking back to the rhetoric of 1945. But where the two disagreed was on Thatcher's Atlanticism and to a certain extent her views on Europe because Powell believed that in the long run they would jeopardise British sovereignty and even worse, fail to protect the conservative nation. Powell had set the trend of identity politics to identify defenders and opponents of the British state. Fundamentally for him, values were transcendental and could not or should not be fought for. Yet what he misunderstood was the force of the free market that once unleashed under Thatcher, would prove to be a far more revolutionary power than any of the other social dynamics he feared.

Part II of this book deals with the Thatcher years per se and the first contribution written by Laura Beers analyses the Conservative's Party appeal to women during the 1980s given the progressive swing in women's support for Labour. Beers begins with an assessment of the gender gap in British politics underlining the fact that different survey results showed a tendency for this to decline in the 1980s. These findings intrigued political scientists given Mrs Thatcher's overt lack of support for feminism and the causes generally defended by women's movements and prompted them to examine women's so-called deviant electoral behaviour or apparent conservatism. Yet even if sex no longer seems to be a viable indicator of political preference, this "dealignment" has not put an end to either generational divisions among female voters or motivational ones between the two sexes. On many occasions, these latter have proven to alienate women voters from the Conservatives rather than attract them to the Labour Party, except for those on the same hard-line moral wavelength as the Prime Minister. Thatcher appealed to women by emphasising her housewife-come-mother-come homemaker's approach to politics, in short by promoting the family as being the main social unit. According to her, it is in this sphere that women achieve their essential purpose, which explains her government's reticence to promote policies that might have encouraged them to shirk these responsibilities. The author continues her analysis by providing detailed poll data about women's reactions to Thatcher as a role model. Generally speaking, they reacted more positively than their male counterparts to Thatcher's influence on politics or at least would publicly admit their admiration for her. Labour was intrigued by women's liking Thatcher, commissioned research and found once again that her strength of character was an important vote catcher among women electors especially those who identified with success and exceptionalism rather than solely feminist driven equality seekers. The author's argument is the same when it comes to Mrs Thatcher's "housewife" and "common sense" approach to economics whereby countries should organise their economies along the same lines as households and families, spending no more than they earn. Yet, attitudes to government spending show slightly different approaches according to sex, especially in the fields of welfare, employment and above all, education. The Conservative's knew full well that this was traditionally an issue that women - and especially mothers - felt more strongly about than men and deliberately played the education message in respect of this potential support. The author's main contention is that the emphasis on Thatcher's "law and order" appeal to women has obscured other important aspects of their support for her and that by breaking down poll data, sub trends can be established that explain to what extent the powerful housewife figure of Mrs Thatcher attracted so much support from women during the 1980s.

The following contribution deals with the decline of class politics in Mrs Thatcher's Britain with the authors contending that it was her own class image which prompted her to aim for a more positive and classless vision of politics. Added to this was the creation of a new range of oppositions within British society that left little room for the "class" argument all the more so as Thatcher herself believed in ordinary people who would adhere to the "ordinary" universal 
values she promoted rather than those dictated by nebulous class distinctions. Hence the creation of a new class constituency that revolved around the "middle" of the country sharing Thatcher's commonsense and ordinary values, their common enemy being, if all went well, socialism. To highlight this transition, the authors, Jon Lawrence and Florence SutcliffeBraithwaite, take a step back in time and describe the post-war historical backdrop against which class distinction took place. They maintain that moving the goalposts of affluence was not necessarily accompanied by a transfer of corresponding values, especially given that stereotypes - especially those conveyed by popular media, and culture - die hard. The idea of a class ridden society was still manifest and social science seemed to tap into this trend thus opening up a breech which Thatcher and her disciples could exploit adroitly. This they did by decontaminating the middle class and relabeling it the "aspirational" class, who shared her affection for ordinariness but whose members would nevertheless endeavour to improve their lot whatever their background or life circumstances. Once again, it was the socialist class construct that she abhorred preferring the rugged individualism that was to characterise her own vision. Housing and tax were used conspicuously in the crusade not only to encourage individual responsibility, but also legitimise material improvement. These efforts were somewhat timid in 1979 due to the belief that promising material improvement was not enough to secure victory and that some compromises had to be accepted. Yet the future electoral victories in 1983 and 1987 were to enable the Conservatives to slay the giants of economically and occupational definitions of class and replace them with a vision based on individuals and families: ultimately this was part and parcel of their strategic onslaught on the socialist collectivism that they felt was at the heart of all society's evils.

The 1984-1985 miners' strike is one of the outstanding events during the Thatcher years pitting the reinforced legislative arsenal of the state against the specific cultural and industrial forces of the miners. David Howell recounts the evolution of trade unionism within the industry and the impact on union truculence of differential wage structures and government imposed productivity targets as from the late 1970s. A detailed account of the strike itself is provided and the author lays particular emphasis on the multitude of divisions and disputes that appeared within the movement itself at all levels, especially when the legality of strike movements was challenged in the courts. The overall impression the reader gleans is that much of the strike movement escaped the control that any national mining authority, union or otherwise, would have been keen to enforce. Howell concludes by dealing with the legacies of this episode on politics and points out the shift of support from Labour to both the Conservative Party and the Liberal-Social Democrats. He contends that industrial relations within the mining sector were damaged beyond repair during this period but suggests that the very culture of the mining industry was just as much to blame for this as any attempt by the main political actors to reap benefit from any kind of fragmentation of the union movement.

The following contribution is devoted to the different brands of devolution promoted in Scotland and Wales and begins by identifying the different concepts of unionism, unitarianism and nationalism, all prone to misinterpretation. The author, Richard Finlay, then points out the importance of class identities and civic nationalism in the devolution debate. The first part of the chapter deals with unionism in both countries and kicks off with an analysis of electoral fortunes of the main parties there, underlining the fact that electoral systems can potentially distort results and in the case of Scotland, amplified what was widely perceived to be an outright rejection of Thatcherism and the Conservative Party. Thatcher tried to appeal to nationalist sentiment especially in Scotland but somewhat unwittingly tended to advocate unitarianism rather than unionism in the name of British uniformity and "sameness". Yet this latter concept came across a major stumbling block namely public sector agencies which the thatcherites were busy dismantling but to which both the Scottish and Welsh were particularly attached as one of the raisons d'être for the post-war union in the first 
place. Thatcher's main failing was indeed her inability to deal adequately with sub-British identities just as she failed to engage correctly with regional ones. Instead, her Party would merely preach the financial benefits of union for the Welsh and the Scottish thus giving the impression that they ignored the wider issues linked to nationalism. This left Labour and the Liberal Democrats to champion the cause of devolution as a response to the democratic deficit caused by the almighty strength of the Conservative Party in England, all the more so in Scotland which enjoyed greater territorial integrity. The author pursues his analysis by relating the major socio-economic changes that affected Great Britain during the Thatcher years. He contends that both countries and whole communities suffered acutely from deindustrialisation which was perceived as being an assault on working class culture, another wedge driven between areas of the "old" and the "new" economy. In Wales and Scotland, this is precisely what generated the most hostility towards Thatcherism and exacerbated nationalistic, territorial tendencies far more than any fragmentation of the political parties due to issues linked to the Falklands, the miners' strike, the Poll Tax or even devolution itself. The author pursues his argument by broaching the question of how the notion of "civil society" was used in both countries. In Scotland, it was used to unite the opponents of Thatcherism and enabled them to foster a form of popular sovereignty but as the author is quick to point out, it was also a short cut used by those who had lost out from the Thatcherite revolution to return to the political limelight, rid their claims of the traditional class structure argument and portray Thatcher and her party as being quite simply alien to Scots and Scotland. In Wales, the same "myth" of civil society was far less exploited to conjure up a national response to Thatcherism especially given the loyalty to traditional class structure, the ethnic nationalism that Plaid Cymru tended to be associated with and the lack of territorial insularity. Richard Finlay concludes by stating that the same socio-economic consequences of Thatcherism produced different results in the two countries: in Scotland a more national response to Thatcherism was manufactured by accusing Britishness of being mere Englishness whereas in Wales, traditional structures of society came under less assault and therefore there was a lesser need to throw up a national barricade to reject the effects of Westminster government.

The following author tackles the question of Ireland and starts by surveying the different settlement frameworks available based on the east-west, Catholic-Protestant, north-south axes. Marc Mulholland adroitly explains the articulation of rights, duties and claims between Britain and Ireland before suggesting that Britain's constant change of tack over the course of the Troubles fuelled inconsistencies that were hardly propitious to uniting the feuding communities. He underlines the fact that Thatcher herself, on becoming Prime Minister, rapidly crystallised all the bitterness and hatred generated by the protracted dealings linked to the Irish question. A great deal of this was due to her overt contempt for the Irish nationalist identity while her distrust of so-called catholic alienation from state institutions during the rapprochement process also ruffled many feathers. This explains why many policies were hammered out by articulate civil servants with expert knowledge who could then rely on the authority of the Prime Minister for implementation. The 1985 Anglo-Irish Agreement smacks of this logic but the author contends that it was Thatcher's way of bolstering the middle ground against the extremes given her constant obsession with security considerations. This attitude contributed inevitably to the electoral success of Sinn Féin as they moved away from armed struggle, the extreme that Thatcher despised above all others.

Part three of this book deals with Thatcherism and the wider world. The first author, Richard Vinen, looks at Thatcherism through the prism of the Cold War and devotes his first part to defence policy. He notes that 1979 did not usher in any major change given mainly that there has always been a high level of consensus in this field given the degree of highly specialised knowledge it requires. To this end, the commitment to the free market left defence largely unaffected while Thatcher's skills in military matters were often - silently - questioned 
by those bemused by the so-called incongruity of a woman becoming involved, all the more so as she had never worn military uniform. In fact, the biggest changes in defence questions during Thatcher's premierships were raised by the Labour Party who were openly turning their backs on Britain's nuclear deterrent. The backlash on this was substantial especially after the Falklands War which ensured a considerable electoral victory for the Conservatives in 1983 and also devastated Labour's political credibility for years to come, voters believing that a leading member of NATO could not suffer such humiliation in the Cold War context of the 1980s. This latter also dictated Thatcher's view of other European countries and leaders: despite her distrust of Europe, she had good relations with European leaders and indeed countries who would stand firm on their allegiance to the western block. She was prepared to accommodate the Soviet Union given her belief that it could not be changed and her Atlanticism - especially during Reagan's two mandates - was geared towards elaborating containment policies designed to thwart the spread of communism. Towards the end of her premiership, Thatcher saw herself increasingly as an international statesperson having played a crucial role in ending the Cold War characterised by the fall of the Wall. But as her role on the international scene became more personified, so did her reputation for eccentricity, the prerogative of great leaders with vast experience. But the end of the Cold War reduced Britain's thirst for greatness given that unity vis-à-vis the Soviet block was no longer necessary. This provides some explanation for her wariness about the construction of the European Union given that the threat from the east was gradually dwindling. Thatcher wanted Britain to be a great world power and believed that economic success was a key element in achieving this if only because, like other European countries, the military power of Britain exceeded the country's economic power. Vinen concludes by stating that one of Mrs Thatcher's strengths was the ability to combine radicalism and pragmatism in her approach to the Cold War the result of which was to redefine Britain's greatness - and thus her own where military power was not the only defining element.

In the following contribution Andrew Gamble deals with the evolution of Thatcher's relationships with the international community and especially with Europe and America. To explain why and how Thatcher managed to bequeath a Eurosceptic identity on her party, the author looks back at the three phases through which the Conservative Party moved namely pro-European, to increasing scepticism followed by a renewed interest in her links with America. The first part deals classically with the decline of the British Empire and her subsequent "natural" desire to turn towards her more immediate European partners while maintaining her "special" relationship with America. Thatcher was to put an end to this zealous attitude vis-à-vis the construction of Europe within her party. Gamble's second part deals with the security community to which Britain was so eager to be part of to the extent that her governments would readily show subservience to the American "master". Thatcher followed suit but managed to underline the need for strong American leadership by focusing attention on security policy given the expansionist threat posed by the Soviet Union and her support was characterised by the use of airbases and the siting of American missiles on British soil. Likewise her personal relationships with world leaders; none was so strong as the friendship she cherished with Reagan as stated elsewhere in this book, and despite upsets caused by the Falklands crisis and the US intervention in Grenada, there is no denying that Britain's Atlanticism was by and large rekindled during Thatcher's premierships. The collapse of communism in Europe allowed Britain and America to revel in the bond they had created around liberal capitalism and the knowledge that they had created a new world order in which their leadership in the quest of freedom would be paramount. With this in mind, it goes without saying that the European project would be relegated to a secondary level. Yet Thatcher's attitude towards Europe was ambiguous given the zeal with which she promoted a free market eurozone on the one hand while shirking the collective responsibilities that the 
community set out to foster on the other. The author explains how this divided the Conservative Party forcing the different factions into defining their perceptions of Britain's overall political economy, whether they believed more in the American model or the continental one. Where Thatcher stands out particularly on this issue is the link she made between security, defence and political economy, emphasising the advantages Britain would have by remaining faithful to its Atlanticism for all three. This explains her promotion, along with her accomplice Ronald Reagan, of the Anglo-American model of capitalism as opposed to any European social model of society. This was portrayed as being a strategic choice for the country settled in political economy terms. Gamble ends his contribution by reflecting on the ideological community that Thatcher was supposed to have inspired and how her particular brand of realpolitik meshed in with the "grand design" often associated with Thatcherism. Between Britain and America there was indeed the ideological potential to move mountains and for Thatcher, this was to be used in order to reverse British decline. Thus her neo-liberalism was designed to bolster economic prosperity, unleash market forces and in doing so, ultimately slay the Giant socialism. The finer details were perhaps ignored or only partially understood but the overall picture of a free economy corresponded to Thatcher's instinct to what she believed was "international common sense", based on the model of Anglo-Saxon capitalism. To this end, Thatcher was particularly skillful in identifying British interests in accordance with the way America defined her own interests, not as any sort of rival but an accomplice underling willing to recreate the old Anglo-American bond based on common traits of national character. Thus Britain had bounced back from a former position of wariness vis-à-vis "Americanisation" which embodied high modernity and the constant adapting of culture. Although many Conservatives found this latter aspect difficult to assimilate, Thatcher managed to make Britain's interests in security, political economy and ideology converge in one direction namely the United States, and there could be no - or at least very little - alternative.

The last contribution attempts to provide coherence to the "end of empire" narrative during the Thatcher years. Stephen Howe insists from the outset on the imbrication between imperial, colonial and British history and begins his analysis by delving into the background of Thatcher and empire. To many intents and purposes Thatcher was one of the most "aimperial" political leaders Britain has ever had and although she would never apologise for colonisation, neither would she indulge in imperialist leanings. Howe takes the reader through some of the main incidents that occurred during the Thatcher years that had strong links with the legacies of empire and points out the Prime Minister's idiosyncratic behaviour during the Rhodesian crisis, the Falklands War - which for many stands out as the defining point of Britain's imperial past during the Thatcher years -, the US invasion of Grenada, South Africa and Hong Kong. For the author, these can be considered as mere post imperial "episodes" and he follows these descriptions with an attempt at defining the bigger picture of internal decolonisation within Britain itself: the decline in Britain's national purpose, identity and even economy can be linked to the decline of the Empire with the Falklands episode redressing this momentarily; the desire for independence expressed by Scotland, Wales and Northern Ireland is the "natural" conclusion to the end of the empire while Thatcher's attitude to some regions or even towns in Britain smacked of her country's attitude towards former colonies. Yet Howe believes that by focussing so much attention on decolonisation, too little has been said about the continuities of the Empire, for despite claims of decline, Britain still holds a world role. To link this to the Thatcher years, Howe identifies four defining developments: the reintegration of the Dominions into the "end-of-empire" story, internal decolonisations within Europe especially amongst former imperial powers where the consequences of imperial memory on national identities has been potent, the Europeanisation of decolonisation which tends to show that European integration and Atlanticism are not 
mutually exclusive and lastly, the relationship between decolonisation and the AngloAmerican partnership.

Making Thatcher's Britain provides invaluable insight into the role the Thatcher years have played in twentieth century Britain. To this end, the authors' claim to originality is genuine and the goal achieved. Nevertheless specialist knowledge of the period is a prerequisite to drawing full benefit from reading given that each author's focus is highly specialised, technical and detailed. This is therefore a book for advanced students who have an interest in political science and the contemporary history of Great Britain and who are interested in an analysis of the 1980s that does not isolate the period from the rest of the century as if Thatcherism should be considered as being out on a limb rather than part of the whole picture. There is indeed a "before" and an "after" Thatcher and this set of articles provides the links that are necessary to understand what Britain has become since the Iron Lady's occupancy of $\mathrm{N}^{\circ} 10$ Downing Street. 